\section{ACADEMIC AND INDEPENDENT DRAWING DURING THE FIRST YEAR OF STUDY IN THE SYSTEM OF TRAINING FUTURE DESIGNERS}

\author{
Valeriy Dmytrenko, \\ https://orcid.org/0000-0001-7003-7544 \\ Senior Lecturer \\ at the Department of the Fine Arts, \\ Kryvyi Rih State \\ Pedagogical University, \\ Kryvyi Rih, Ukraine \\ miner8924@gmail.com
}

\section{АКАДЕМІЧНИЙ ТА САМОСТІЙНИЙ РИСУНОК НА ПЕРШОМУ КУРСІ В СИСТЕМІ ПІДГОТОВКИ СТУДЕНТІВ-ДИЗАЙНЕРІВ}

\author{
Валерій Дмитренко, \\ https://orcid.org/0000-0001-7003-7544 \\ старший викладач \\ кафредри образотворчого мистецтва, \\ Криворізький державний \\ педагогічний університет, \\ Кривий Ріг, Україна \\ miner8924@gmail.com
}

\section{Abstract}

The aim of the article is to consider the most efficient way to organize the learning process of the academic subject "Drawing" during the first year of study in the system of training designers. This process should fully meet the requirements of educational reform, where an academic drawing would be directly connected with creative activity and would contribute to the formation of knowledge and skills necessary for a designer. The methodology of the research is to find the most efficient way of organization of the learning process where classroom work, self-studying work and homework could be effectively combined with scientifically grounded educational-methodological system of professional art training. The scientific novelty lies in the balanced structuring of the tasks in the curriculum of the subject "Drawing" for both classroom work with an academic focus, and self-studying work with a creative focus which will enhance the effectiveness of teaching the subject in the face of limiting the number of academic hours. Conclusions. The subject "Drawing" still remains the basis of artistic education in the system of training of designers, but it requires some changes in the ways teaching and methodical process are organized, which are caused by the specific character of the subject closely related to the designer's work.
Анотація

Метою дослідження є розгляд найбільш оптимальної організації навчального процесу з дисципліни «Рисунок» на першому курсі в системі підготовки дизайнерів. Такий процес повинен найбільш повно відповідати вимогам реформи освіти, де академічний малюнок був би безпосередньо пов'язаний з творчою діяльністю та сприяв би формуванню знань, вмінь, навичок, необхідних дизайнеру. Методологія дослідження полягає в пошуку розумної форми організації навчального процесу, яка б поєднувала аудиторну, самостійну та домашню роботу в науково обґрунтовану навчально-методичну систему професійної та художньої підготовки. Наукова новизна полягає в раціональному структуруванні завдань навчальної програми «Рисунок» на аудиторні закадемічним спрямуванням та самостійні з творчим спрямуванням, що дозволяє підвищити ефективність викладання дисципліни в умовах обмеження кількості академічних годин та збільшення часу, відведеного на самостійне опрацювання. Висновки. Дисципліна «Рисунок» залишається основою художньої освіти в системі підготовки студентів-дизайнерів, але в сучасних умовах існує необхідність певних змін в організації навчально-методичного процесу, які обумовлені специфікою дисципліни, тісно пов'язаної з творчістю дизайнера. 
Деміург: ідеї, технології, перспективи дизайну 2019 Том 2 № 2

Demiurge: ideas, technologies, perspectives of design 2019 Vol. 2 No 2

\section{Keywords: Ключові слова:}

drawing, learning process, reform, classroom work, self-studying work.

рисунок, навчальний процес, реформа, аудиторні заняття, самостійна робота.

Вступ 11 Професія дизайнера є однією із найбільш поширених творчих професій нашого часу і тому перед навчальними закладами, які ведуть підготовку студентів цього напряму, стоїть серйозне завдання підвищення якості підготовки. Актуальною ця проблема є також для викладачів малюнка, яким необхідно навчати не майбутнього художника, а дизайнера з конкретною спеціалізацією, що вимагає зміни направленості цілей та задач навчальної дисципліни.

Рисунок як навчальний предмет є основою підготовки та творчої діяльності сучасного студента-дизайнера. Ця навчальна дисципліна забезпечує йому можливість вільно виражати свої ідеї та задуми у навчальній та творчій роботі, а це визначає роль малюнка як базової дисципліни. Рисунок $є$ одним з найважливіших навчальних предметів для засвоєння таких фундаментальних понять як закони перспективи, закони розподілу світлотіні, засвоєння методики виконання зображення, вивчення способів конструктивної побудови.

Проте існує певна інерція у викладанні рисунку для студентів спеціальності «дизайн», пов'язана з тим, що викладачі мають академічну художню освіту. Попри те, що перед дизайнерами стоять принципово інші творчі задачі та цілі, викладання рисунку в сучасних умовах ведеться такими ж методами, як і для студентів класичного художнього спрямування. Крім того, у зв'язку з реформуванням системи освіти в навчальних планах останніх років існує стійка тенденція до зменшення кількості аудиторних годин та збільшення кількості годин, відведених на самостійне опрацювання навчального матеріалу, а це також вимагає перегляду підходів до викладання дисципліни.

У зв'язку з цим є необхідність переглянути організацію навчального процесу та розробити робочу програму з рисунка таким чином, щоб забезпечити високу якість засвоєння фундаментальних знань з образотворчого мистецтва та дати студентам можливість розвивати свій творчий потенціал та здобувати професійні навички, необхідні в навчальній та творчій роботі дизайнера.

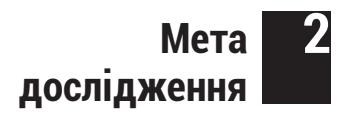

Для створення повноцінної творчої роботи у сфері дизайну студенту необхідно володіти малюнком. Проте повинна існувати чітка відмінність між навчальним рисунком для студентів образотворчого спрямування і навчальним рисунком для сту- 
дентів дизайнерів. Головною відмінністю академічного малюнка для підготовки майбутніх дизайнерів повинен бути акцент уваги на побудові форми, тобто на конструкції, пропорціях та сприйнятті форми у просторі, а це буде вимагати від студента не сліпого копіювання, а вміння розмірковувати формою. Також потрібно забезпечити студенту можливість розвивати свої творчі здібності, пов'язанні зі специфічною діяльністю дизайнера, здобувати професійні навички та вміння із застосуванням різноманітних художніх матеріалів.

У зв'язку зі скороченням кількості годин на аудиторні заняття зменшується кількість часу, який можна використати на вивчення фундаментальних основ образотворчої грамоти та, одночасно, займатися творчою діяльністю, пов'язаною зі специфікою дизайну. Це може спричинити або недостатню якість академічного навчання, або слабку творчу підготовку. Але ж задача академічного рисунка, особливо на початковій стадії навчання, - дати студенту ґрунтовні академічні знання. Це є проблемою сучасного стану викладання навчальної дисципліни. Одним зі способів її розв'язання може бути перенесення всіх творчих задач, пов'язаних зі специфікою підготовки дизайнера, та експериментальної діяльності з різними художніми матеріалами на самостійну та домашню роботу, організовану викладачем та під обов'язковим контролем викладача.

Метою дослідження є пошук раціональної організації навчального процесу з дисципліни «Рисунок» на начальному курсі, який найповніше б відповідав вимогам реформи системи освіти, вдало поєднував би навчальну роботу з вивчення фундаментальних знань образотворчого мистецтва та сприяв би розвитку творчого потенціалу, умінню працювати з різними художніми матеріалами, здобуттю вмінь і навичок в практичній роботі.

Методологія та аналіз джерельної бази
Академічний рисунок $є$ основною навчальною дисципліною в системі художньої освіти та естетичного виховання майбутніх дизайнерів. Початковий етап занять з малюнку є періодом, важливість якого важко переоцінити. В цей час студент отримує основи грамоти реалістичного зображення, здобуває уміння, навички, прийоми у створенні зображення на площині. В ході цієї роботи, що базується на малюванні з натури спочатку простих геометричних тіл, а потім складних предметів побуту, студент вчиться розуміти та зображувати об'ємну форму за допомогою конструктивної побудови та перспективи. Також студент засвоює закони світлотіньової градації об'ємної форми та здобуває вміння їі зображувати, вчиться знаходити пропорційні тонові відношення між градаціями світлотіні на об'ємних формах та між тонами окремих об'єктів натурної постановки, 
оволодіває навичками в застосуванні лінії та штриха в тональному малюнку натюрморту та начерку.

Завдання з дисципліни повинні поступово ускладнюватись, зберігаючи відповідність принципу систематичності та послідовності навчання. Тільки після того, як студент опанує основи знань, умінь та навичок у зображенні натури, він може переходити до вивчення складніших навчальних задач, таких як зображення інтер'єру, пейзажу, малювання голови та фігури людини, створення складних композицій. Крім того, студент повинен виконувати завдання, пов'язані з його спеціалізацією, які б вирішували задачу розвитку творчих здібностей, здобуття умінь та навичок, необхідних у навчальній та творчій діяльності дизайнера.

Методологія дослідження полягає у пошуку необхідної форми організації навчального процесу з використанням аудиторної, самостійної та домашньої роботи, яка б забезпечувала можливість досконалого вивчення студентами фундаментальних основ образотворчого мистецтва, надавала б можливість опанування методами зображувальної грамоти, давала б перспективу здобуття та розвитку професійних навичок та вмінь, стимулювала б творчу активність під час навчальної та професійної діяльності.

В ході написання даної статті не розглядаються дисципліни спеціальної підготовки дизайнерів, а проводиться дослідження тільки в контексті навчальної програми «Рисунок».

В умовах сучасної реформи системи освіти відбувається поступове заміщення академічних годин часом, що відводиться на самостійне опрацювання. Це скорочення кількості академічних годин сильно обмежує можливості викладача щодо повноцінного викладання матеріалу комплексу дисципліни «Рисунок» з подачею теоретичних фундаментальних знань, практичною навчальною роботою та стимулюванням творчої діяльності та художнього експерименту.

Одним з авторів, що вивчають дану проблему, є доцент Київського національного університету культури та мистецтв С. Лопухова, яка проводить дослідження з пошуку нових форм викладання академічного рисунка. Вона розглядає питання поєднання класичного методу ретельного студіювання натури з метою опанування головних принципів відтворення тривимірного зображення на площині та методу творчого експерименту, суттю якого є інтеграція фундаментальних художніх дисциплін і застосування новітнього технологічного інструментарію для практичного втілення образу. Зокрема вона відзначає, що модернізація навчального процесу вимагає реформування системи традиційного підходу до викладання рисунку. Народжуються нові освітні концепції, у навчальний процес активно 
впроваджуються нові дисципліни з колосальними навчальними ресурсами, застосовується новий технологічний інструментарій, затверджуються нові державні нормативи, за якими жорстко скорочується обсяг часу, відведеного на вивчення фундаментальних художніх дисциплін, і стає зрозумілим, що класичну форму викладання рисунку у цих умовах зберегти неможливо. Тобто необхідно шукати нові форми засвоєння матеріалу, реагуючи на всі зміни соціальних умов і вимог (Лопухова, 2018, с. 42-43).

Історичний процес відмови від традиційних академічних методів розглядає у своїх роботах кандидат мистецтвознавства, доцент Криворізького державного педагогічного університету І. Удріс. Вона відзначає, що вагомий етап еволюції дизайн-освіти XX ст., якому дав поштовх Баугауз, сформувався під впливом запитів індустріального суспільства часів його розквіту. Сутність пошуків того часу окреслив піонер інженерної естетики Ле Корбюзьє, упевнений, що машина втілює особливий стан духовності, а геометрія ібоги царюють на одному престолі. У цей час панують пріоритети промислового функціонального дизайну і сформульоване кредо, що проіснувало півстоліття та визначило ознаки якісного дизайн-виробу в такій послідовності: конструктивність, технологічність, функціональність, ергономічність та естетичність. Продовжуючи свою думку, І. Удріс (2017) робить висновок, що важливо уважніше поставитись до методики викладання базових дисциплін. Так, не доцільно за однією програмою викладати історію мистецтва для художників-педагогів і дизайнерів. Щодо рисунка й живопису, то поряд з академічними завданнями, що забезпечують загальну художню культуру, необхідно ширше вводити експериментальні вправи, які розвивають аналітичне мислення як основу проектно-образного мислення дизайнера (с. 26-27).

Визначення специфіки навчального рисунка як однієї із провідних дисциплін упідготовці майбутніх спеціалістів галузі дизайну проводять у своєму дослідженні О. Алієва, доцент уральської державної архітектурно-художньої академії, та Т. Субботіна, старший викладач цього закладу. Вони звертають увагу на те, що при розгляді даної проблеми є доцільним звернутися до багатого досвіду школи малюнка Санкт-Петербурзької державної художньо-промислової академії ім. А. Л. Штігліца: «викладання малюнка вхудожньо-промисловому ВНЗ має здійснюватися в тісному взаємозв'язку між малюванням загальним - «академічним» і спеціальним, призначеним для застосування у будь-якій конкретній галузі творчості». Програма і побудований на ї̈ основі навчальний план забезпечують опанування студентами теоретичних знань. У положенні загального навчального плану ЦУТР барона Штігліца вказуєть- 
ся, що академічний малюнок, «розвиваючи художнє почуття і розуміння, не має на увазі вищих, суто художніх цілей», як, наприклад, в Інституті ім. І. Ю. Рєпіна, «а прикладна мета мистецтва - його застосування до промислових виробництв і ремесел. Інакше навчальний заклад не виконає свого завдання і тільки перетвориться в погану академію мистецтв» (Алиева \& Субботина, 2018, с. 45). Минуло більше століття з того часу, як було сформульовано згадану тезу, але вона й сьогодні залишається справедливою.

Результати
дослідження
Одним із найважливіших завдань навчального курсу є надання фундаментальних знань у галузі образотворчого мистецтва та створення можливостей у здобутті студентами вміння професійно грамотно малювати з натури, з пам'яті та уяви, засвоїти технічні навички реалістичного зображення дійсності та їі художньої інтерпретації. Працюючи з натури, студенти зможуть розвинути зорову пам'ять та спостережливість, просторове мислення, навчаться бачити типове у навколишній дійсності. Крім того, заняття малюванням формує естетичний смак, розвиває творчі здібності.

Але сучасні умови вимагають змін до дисципліни «Рисунок» у системі підготовки дизайнерів, у зв'язку з чим виникла необхідність розробити нові методологічні принципи організації навчального процесу і, зокрема, на початковій стадії навчання. Головною задачею буде в умовах скорочення кількості академічних годин так збалансувати академічні заняття та самостійну роботу, щоб у повному обсязі задовольнити потреби студентів у здобутті фундаментальних знань і водночас надати можливість займатися творчим експериментом та мати перспективу застосування широкого діапазону художніх засобів образотворчого мистецтва.

Робоча програма з рисунка повинна відповідати зазначеним вимогам. Найкращим рішенням, на нашу думку, буде відвести академічні години на вивчення фундаментальних законів образотворчого мистецтва, а на самостійній та домашній роботі виконувати завдання з творчими пошуками, виконувати вправи на розвиток образного мислення, завдання щодо творчої інтерпретації зображення. Але цю роботу не можна пускати на самоплив, вона повинна організовуватись і керуватись викладачем, який зобов'язаний ставити задачі, контролювати хід роботи, проводити консультації.

Далі у нашій статті пропонуються конкретні кроки для практичної реалізації даного методу навчального процесу. Під час академічної частини аудиторних годин на першому курсі використовується метод малювання з натури, де студенти засвоюють методи виконання малюнка, починаючи від попереднього 
начерку і закінчуючи завершальною стадією. В ході виконання цієї роботи у процесі безпосереднього зображення студенти засвоюють необхідні знання, у них формуються потрібні професійні вміння та навички, розвивається зорова пам'ять та уява, відбувається «постановка ока».

Основним об'єктом вивчення рисунку на молодших курсах $€$ натюрморти з простих натурних постановок геометричних тіл та предметів побуту, які дозволяють студентам під час практичної роботи здобути необхідний запас теоретичних знань з правил конструктивної та перспективної побудови предметів, опанувати навичками зображувальної грамоти, сформувати світлотіньове мислення. Крім того, під час виконання цих завдань студенти здобувають навички використання різних художніх засобів, розвивають свій естетичний смак та творчі здібності.

Натюрморти повинні складатися таким чином, щоб завдання поступово ускладнювались відповідно до принципу систематичності та послідовності навчання. Це означає, що кожне завдання є продовженням попереднього та, у свою чергу, стає основою для виконання наступного завдання.

На початковому етапі навчання з рисунка для студентів дизайнерів основна увага повинна бути зосереджена на конструктивній побудові предметів постановки з вирішенням питання перспективи та композиції. Студенту потрібно привчатися не змальовувати обриси предметів, а вчитися мислити об’ємно, бачити та розуміти конструкцію.

Академічний курс першого семестру складається із завдань з малювання натюрмортів з поступовим переходом від конструктивного малюнка геометричних тіл до натюрмортів з предметів побуту з конструктивною побудовою і тональним моделюванням. Ці завдання можна розбити на дві групи: на малюнок навчального натюрморту з геометричних тіл та малюнок навчального натюрморту з предметів побуту. У свою чергу кожну з цих груп можна розбити на три завдання.

Перша група:

- лінійний конструктивний малюнок натюрморту з геометричних тіл;

- конструктивний малюнок натюрморту з геометричних тіл з умовним уведенням тону;

- тоновий малюнок натюрморту з геометричних тіл;

Друга група:

- лінійний конструктивний малюнок натюрморту з предметів побуту;

- конструктивний малюнок натюрморту з предметів побуту з умовним введенням тону;

- тоновий малюнок натюрморту з предметів побуту. 
Але, зважаючи на те, що в сучасних умовах часу, відведеного на проведення практичних академічних занять, недостатньо для виконання всіх завдань, то частину з них необхідно перенести на самостійне та домашнє опрацювання, одночасно з виконанням яких студенти будуть працювати над завданнями на розвиток творчих здібностей, здобуття навичок роботи з художніми матеріалами, будуть вчитися виконувати начерки та замальовки. Вся робота повинна проводитися під пильним контролем викладача, навіть тоді коли вона проводиться поза межами аудиторії.

Перші навчальні натюрморти складаються з гіпсових геометричних тіл. Такі навчальні постановки є базовими у вивченні курсу натюрморту, оскільки в основі будови складних форм знаходяться сполучення простих геометричних тіл. Крім того великою перевагою використання гіпсових моделей на початковій стадії навчання є їх однотонність, що значно полегшує сприйняття градацій світлотіні на поверхні. Малювання таких натюрмортів дає студентам можливість вивчити перспективу та розподіл світлотіні на округлих і огранених формах. Засвоєння правил зображення простих геометричних тіл дозволяє студентам перейти до зображення складніших форм та виконання їх світлотіньового моделювання.

Найпершим завданням є лінійний конструктивний малюнок натюрморту з геометричних тіл. Конструктивний малюнок - це основа малюнка, що унаочнює тлумачення об'ємної будови предметів натюрморту. Головною задачею конструктивного малюнка є зображення об'ємної форми предмета у просторі з використанням методу прямої перспективи, де всі паралельні лінії, що йдуть у глибину, сходяться в одній точці на лінії горизонту, та всі предмети з віддаленням у глибину зменшуються в розмірі. Конструктивна побудова виконується за допомогою ліній та дає зображення предметів у вигляді прозорих каркасів.

Форма малюнка - це зображення, виконане на площині. Але пізнаваний світ - не площина, а тривимірний простір. Всі предмети цього світу тривимірні, вони об’ємні, як і сам світ. Мета рисунка - передати у двовимірному просторі площини тривимірний об'єм. В основі навчання малюнку стоїть завдання розвитку у студента здатності мислити об'ємами у просторі і бачити складність світу через прості поняття (Краморов, 2005, с. 5).

Перші завдання виконуються без використання тону - до уваги береться тільки конструктивна побудова з використанням лінійної перспективи. Для цього максимально використовуються графічні можливості лінії, що дозволяють виконувати чітку побудову та створювати ілюзію простору.

Безліч ліній побудови сплітаються в єдиний килим; щоправда, цей килим має істотний недолік - монотонність, одноманіт- 
ність. Це викликане тим, що під час малювання предмету в просторі аркушу за допомогою лінії, створюючи третій вимір, ми не враховували, що й сама лінія знаходиться в цьому просторі. В міру віддалення від нас у глибину картинної площини, тобто площини аркушу, лінія стає менш активною та тоншою - це «ефект туману». Використовуючи такий ефект поки що тільки до лінії, ми вже на цій стадії рисунка отримаємо стан повітряної перспективи, лінійний малюнок набуде глибини. Лінії першого плану малюнку, в міру наближення до вас посилюються олівцем, а лінії другого плану малюнка, в міру віддалення послаблюються гумкою (Краморов, 2005, с. 18).

Наступним завдання є конструктивний малюнок натюрморту з геометричних тіл з умовним уведенням тону. На першому етапі в таких завданнях виконується лінійна конструктивна побудова предметів постановки та зображуються лінією межі тіней власних та тіней, що падають; показуються межі півтіні на тілах обертання.

На другому етапі легким тоном позначаються тіні власні та тіні, які падають, знаходяться тональні відношення в тінях. Потрібно враховувати те, що повітря не є абсолютно прозорою субстанцією і тому зі збільшенням відстані від спостерігача різниця між тоном тіней та освітленими місцями зменшується.

Якщо об'єкт розміщений ближче до очей спостерігача, то промені світла (ті, що відбиваючись від предмета, потрапляють в око спостерігача) будуть проходити через менший шар атмосфери та менша кількість з них буде мати шанс відхилитися від їхнього курсу в результаті зіткнення з частинками повітря та повітряного забруднення. Результатом розміщення об'єкта ближче до очей спостерігача буде ясніше, інтенсивніше та яскравіше зображення видимого об'єкта. Зі збільшенням дистанції у результаті атмосферного ефекту зображення видимого об'єкта буде менш ясним, менш інтенсивним та менш яскравим (Gill, 1991, с. 27).

Щоб передати відчуття повітряної перспективи та створити ілюзію глибини простору, застосовуються умовні прийоми в малюванні, які використовуються під час створення зображення. Для цього тіні на передньому плані зображуються темнішими, ніж на задньому. Тіні, що падають, показуються темнішими, ніж власні; також послаблюється тон цієї тіні пропорційно з віддаленням від об'єкта, який створює тінь. Межа світлотіні зображується темнішою, ніж сама тінь, завдяки чому тінь набуває ознак рефлексу. Звертаємо увагу на те, що межа світлотіні та переходи між світлом та напівтінню на огранених тілах жорсткі, а на тілах обертання - м'які. Крім того, межа світлотіні на кулі має плановість і темніша ближче до середини та світлішає ближче до країв. 
Зображення напівтіні світлішим тоном, аніж тон тіні, дає можливість отримати два компоненти світлотіні, які знаходяться в освітлених місцях моделі. Півтінь на тілах обертання зображується з поступовим переходом від темнішого тону біля тіні та до світлішого тону - чим далі віддаляється від межі світлотіні. На огранених тілах освітлені поверхні зображуються світлішими ближче до межі світлотіні і темнішими - з віддаленням від неї. Важливо, щоб тони тіні, півтіні та світла не повторювали один одного.

Виконуючи тональне опрацювання малюнка, пам'ятаємо, що в цьому завданні головною є лінійно-конструктивна побудова, а умовний тон є доповненням для створення більшої об'ємності та наочності зображення. Тон створюється без прямого орієнтування на натуру, в роботі студент використовує раніше отримані теоретичні знання про закони розподілу світлотіні на поверхні предметів, а натура використовується тільки в якості довідки для уточнювання місцерозташування компонентів світлотіні. Працюючи над цим етапом, важливо обов'язково виконувати зазначені вимоги та не змальовувати бездумно всі тонові плями, які можна побачити в натурі, не вирішуючи при цьому просторових задач та не витримуючи пропорційного тонального стану натури.

Після виконання другого етапу робота над конструктивним малюнком натюрморту з геометричних тіл з умовним введенням тону закінчується. Цей вид завдання можна вважати проміжним етапом перед опануванням тонового малюнка натюрморту з геометричних тіл.

Проте методика роботи над тоновим малюнком натюрморту з геометричних тіл у цій статті не розглядається, оскільки не $€$ ціллю дослідження. Завдання виконується подібно до таких же завдань в інших напрямах підготовки в галузі мистецтва. У зв'язку з тим, що існує безліч професійної літератури з цієї теми, пропонується тільки приблизний порядок роботи:

- конструктивна побудова предметів натюрморту з врахуванням їх просторового положення;

- світлотіньове моделювання великої форми предметів та встановлення основних тональних взаємозв'язків;

- детальне опрацювання форм тоном;

- етап узагальнення роботи над малюнком.

Цим завданням закінчується робота над першою групою натюрмортів академічного курсу, після чого починається новий етап роботи, пов'язаний з малюванням навчальних натюрмортів з предметів побуту. Під час роботи над натюрмортами цієї групи відбуватиметься закріплення отриманих раніше знань з вивчення конструктивної будови форм предметів та моделювання форми засобами світлотіні. Крім того, будуть вирішува- 
тися нові задачі з конструктивної побудови форми складних об'єктів та тонального моделювання предметів натюрморту, які мають різний колір, тон, матеріальність.

Практично всі предмети побуту довкола нас у своїй конструкції складаються з простих геометричних тіл або їх сполучень. Знання цього дає можливість зрозуміти перспективні скорочення натури та її об'ємну будову, допомагає у тональному моделюванні складних предметів, знаходженні правильних тональних взаємозв'язків, передачі матеріальності та рішенні інших задач.

Першим завданням у цій групі натюрмортів будуть два типи завдань: лінійний конструктивний рисунок натюрморту і конструктивний рисунок натюрморту з умовним введенням тону. Лінійний конструктивний малюнок натюрморту з предметів побуту виконується без застосування тону подібно до конструктивного лінійного малюнку натюрморту з геометричних тіл. Основне завдання - це передача об'ємів у просторі за допомогою конструкції та перспективи, зображення предметів постановки у вигляді прозорих каркасів. Тільки в цьому випадку перед студентами стоїть складніша задача з побудови об’ємів предметів, які у своїй конструкції складаються з набору простих геометричних тіл у різних сполученнях.

Наступне завдання - конструктивний малюнок натюрморту з предметів побуту з умовним уведенням тону. В навчальних малюнках такого типу предмети в натюрморті розглядаються як такі, що не мають забарвлення, тому задачею завдання є побудувати об'єми предметів у просторі за допомогою лінії та умовного освітлення.

На першому етапі виконується лінійний конструктивний рисунок предметів постановки із зображенням контурів тіней власних та тіней, що падають. Другий етап виконується подібно до аналогічного завдання з геометричними тілами, але при цьому не береться до уваги локальний тон та колір предметів постановки.

Після здійснення другого етапу робота над завданням з виконання конструктивного малюнку натюрморту з предметів побуту з умовним уведенням тону закінчується.

Цю роботу можна розглядати як етап у роботі над наступним завданням з виконання тонового рисунку натюрморту з предметів побуту. Це основне завдання в початковому навчанні, в якому студент здобуває фундаментальні знання реалістичної зображувальної грамоти. Під час цієї роботи учень засвоює закони світлотіньової градації об'ємної форми та здобуває вміння іï зображувати, вчиться знаходити пропорційні тонові відношення між градаціями світлотіні на об'ємних формах та між локальним тоном окремих предметів натурної 
постановки, опановує навичками володіння лінією та штрихом у тональному малюнку та начерку. Під час виконання такої роботи студент навчається умінню бачити, тобто відбувається «постановка ока».

Професійне поняття «постановка ока», «цільне бачення», «уміння бачити» означає одне і те ж, а саме: бачити тони предметів у загальному підпорядкуванні та не намагатися копіювати кожний предмет окремо. Якщо студент навчиться широко дивитися і на натуру, і на малюнок, не впираючись зором лише в один предмет, а оцінювати всю натуру та малюнок в цілому, з цього моменту він починає працювати як професійний художник (Беда, 1981, с. 46).

Початок роботи над навчальним натюрмортом ведеться так, як було розглянуто в описі малювання конструктивного натюрморту з предметів побуту з частковим уведенням тону. Після цього на наступному етапі виконується тональне моделювання натюрморту методом тональних відношень.

Детально розглядати процес роботи над таким натюрмортом не є ціллю нашого дослідження. 3 цього питання можна знайти достатню кількість фахової літератури. Але під час самостійної та домашньої роботи у виконанні таких завдань крім графітного олівця необхідно застосовувати інші художні матеріали, вчитися виконувати творчу інтерпретацію зображення натюрморту, виконувати вправи на розвиток творчої уяви, мислення, розвиток здібностей, необхідних для професійної роботи дизайнера. Реалізація цих завдань дає необмежені можливості у використанні різних художніх засобів відповідно до задуму та поставленої задачі. Можна лише орієнтовно запропонувати виконання деяких видів творчої діяльності, які повинні мати певну специфіку, пов'язану з навчальним напрямком конкретної дизайнерської спеціалізації:

- завдання щодо створення з уяви або з запропонованих моделей композиції натюрморту;

- завдання з малювання натюрморту з пам'яті;

- створення конструктивного зображення об'ємної композиції з геометричних тіл з врізанням одних предметів у інші;

- творча інтерпретація, стилізація або декоративна трансформація (наприклад, декоративно-площинне стилізоване зображення) попередньо намальованого або нового натюрморту;

- виконання натюрморту з використанням різних графічних матеріалів (туш, перо, пензель, м'які матеріали: вугілля, сангіна, пастель тощо), використання кольору в графічній роботі;

- виконання начерків та замальовок із використанням різних технік та матеріалів. 
Стилізація у мистецтві - це процес надання творчому твору рис іншого стилю. В образотворчому мистецтві за допомогою даного прийому предмети або фігури знаходять умовні форми. В рамках курсу академічного малюнка для дизайнерів проводяться вправи як з аудиторними постановками, так і з природними рослинними і тваринними формами, з пейзажними мотивами. При цьому в хід іде активне використання узагальнення, графічної фактури, контуру, пошук силуету (Алиева \& Субботина, 2018, с. 48).

Для узгодження академічної, самостійної та домашньої роботи є сенс створити орієнтовну таблицю-програму з дисципліни «Рисунок» для першого семестру, в якій будуть системно об'єднанні всі види завдань.

Об'єднана таблиця завдань з дисципліни «Рисунок» у першому семестрі підготовки дизайнерів

\begin{tabular}{|c|c|c|c|}
\hline $\begin{array}{l}\text { № зав- } \\
\text { дання }\end{array}$ & $\begin{array}{c}\text { Академічні аудиторні } \\
\text { заняття }\end{array}$ & $\begin{array}{c}\text { Самостійні аудиторні } \\
\text { заняття }\end{array}$ & Домашня робота \\
\hline 1 & $\begin{array}{l}\text { Лінійний конструк- } \\
\text { тивний малюнок } \\
\text { натюрморту з геоме- } \\
\text { тричних тіл }\end{array}$ & $\begin{array}{l}\text { Створення конструк- } \\
\text { тивного зображення } \\
\text { об'ємної композиції } \\
\text { з геометричних тіл } \\
\text { з врізанням одних } \\
\text { предметів у інші }\end{array}$ & $\begin{array}{l}\text { Завдання щодо } \\
\text { створення з уяви або } \\
\text { із запропонованих } \\
\text { моделей композиції } \\
\text { натюрморту }\end{array}$ \\
\hline 2 & $\begin{array}{l}\text { Конструктивний } \\
\text { малюнок натюрмор- } \\
\text { ту з геометричних тіл } \\
\text { з умовним введен- } \\
\text { ням тону }\end{array}$ & $\begin{array}{l}\text { Лінійний конструк- } \\
\text { тивний малюнок } \\
\text { натюрморту з пред- } \\
\text { метів побуту }\end{array}$ & $\begin{array}{l}\text { Завдання змалю- } \\
\text { вання натюрморту } \\
\text { з пам'яті }\end{array}$ \\
\hline 3 & $\begin{array}{l}\text { Конструктивний ма- } \\
\text { люнок натюрморту } \\
\text { з предметів побуту із } \\
\text { умовним уведенням } \\
\text { тону }\end{array}$ & $\begin{array}{l}\text { Тоновий малюнок } \\
\text { натюрморту з геоме- } \\
\text { тричних тіл }\end{array}$ & $\begin{array}{l}\text { Виконання начерків } \\
\text { та замальовок з ви- } \\
\text { користанням різних } \\
\text { технік та матеріалів }\end{array}$ \\
\hline 4 & $\begin{array}{l}\text { Тоновий малюнок } \\
\text { натюрморту з пред- } \\
\text { метів побуту }\end{array}$ & $\begin{array}{l}\text { Творча інтерпретація, } \\
\text { стилізація або деко- } \\
\text { ративна переробка } \\
\text { (наприклад, деко- } \\
\text { ративно-площинне } \\
\text { стилізоване зобра- } \\
\text { ження) попередньо } \\
\text { намальованого або } \\
\text { нового натюрморту }\end{array}$ & $\begin{array}{l}\text { Виконання натюр- } \\
\text { морту з використан- } \\
\text { ням різних графічних } \\
\text { матеріалів (туш, } \\
\text { перо, пензель, м'які } \\
\text { матеріали: вугілля, } \\
\text { сангіна, пастель } \\
\text { тощо), використання } \\
\text { кольору у графічній } \\
\text { роботі }\end{array}$ \\
\hline
\end{tabular}

Завдання академічної групи виконуються на білому аркуші паперу за допомогою графітного олівця. Самостійна та домашня роботи виконуються з використанням різноманітних зображувальних художніх матеріалів та із застосуванням різних основ, придатних для малювання, у залежності від задач та творчого задуму. 
Запропонована програма дозволяє об'єднати в навчальному процесі різні види рисунка - академічного, який базується на малюванні з натури навчальних натюрмортів і надає основні базові знання з образотворчого мистецтва, та творчого або декоративного рисунка, який розвиває творчі здібності, дає навички роботи з різноманітними художніми матеріалами. Академічні і творчі завдання проводяться практично в один і той же період часу, доповнюючи один одного, але не заважаючи виконанню конкретних специфічних навчальних або творчих задач, які присутні у різних розділах навчальної діяльності.

\section{Наукова новизна та практична значимість дослідження

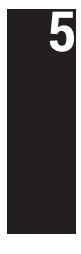

Організація навчального процесу з дисципліни «Рисунок» на початковому курсі з проведенням академічних занять, зосереджених на засвоєнні фундаментальних знань образотворчого мистецтва, й самостійної та домашньої роботи з творчим спрямуванням, повинна забезпечити всебічну підготовку студента-дизайнера. Такий підхід сприятиме здобуттю ним професійних умінь і навичок, розвитку творчих здібностей, необхідних у навчанні та роботі. Самостійна та домашня робота обов'язково організовується та виконується під наглядом викладача.

Розробка робочої програми з дисципліни «Рисунок» з врахуванням висновків даного дослідження повинна підвищити ефективність викладання предмету. У результаті її застосування прогнозується підвищення якості професійної підготовки студентів-дизайнерів на початковому етапі навчання.

\section{Висновки 6}

В даному дослідженні розглядалося питання визначення специфіки навчального малюнка в умовах реформування освіти. Особливості викладання предмету «Рисунок» на початковій стадії підготовки студентів-дизайнерів засвідчують, що академічний малюнок залишається основою художньої освіти та професійної підготовки. Навчальна дисципліна є одним з найкращих засобів вивчення навколишньої дійсності та способів іiі зображення на площині, вона є незамінним інструментом безпосереднього відображення ідей та відчуттів студента та знаряддям реалізації особистого задуму.

Одночасно стан системи освіти в сучасних умовах, яка знаходиться в стадії трансформації, вимагає знаходити нові рішення в організації підготовки дизайнерів та створення нової науково обґрунтованої навчально-методичної системи професійно-художньої підготовки. У зв'язку з цим перед дисципліною «Рисунок» в умовах зменшення кількості академічних годин і збільшенні уваги до самостійної роботи студентів стоїть дилема - як дати базові знання з дисципліни та при цьому не зробити академічний малюнок відірваним від спеціалізації дизайне- 
ра, та як дати студенту певний поштовх до творчої діяльності і бажання займатися творчим експериментом у навчанні.

У статті досліджується питання організації навчального процесу та створення програми з дисципліни «Рисунок», які відповідали б вимогам сучасного стану. Пропонується скласти програму таким чином, щоб студент міг навчитися не тільки відтворювати форму з натури, але і вміти творчо її перетворити, знаходячи конструктивні, пластичні, декоративні, матеріальні якості, навчитися, крім найбільш використовуваного інструменту зображення в навчальній діяльності графітного олівця, уміло використовувати й інші графічні засоби (туш, фломастер, перо, пензель, м'які матеріали, кольорові олівці, акварель, гуаш тощо).

Отже, в результаті аналізу особливостей викладання дисципліни «Рисунок», можна підсумувати, що рисунок, як завжди, $€$ основою художньої освіти та естетичного розвитку у системі підготовки студентів-дизайнерів, але потребує певних змін у порядку організації навчально-методичного процесу. Необхідність таких змін обумовлена специфікою навчальної дисципліни, яка тісно пов'язана з творчістю дизайнера.

\section{Список бібліографічних посилань}

Алиева, О.О., \& Субботина, Т.В. (2018). Особенности академического рисунка в обучении дизайнеров. В Культурологические чтения - 2018. Межкультурный плюрализм в поликультурном и полиязычном мире, Сборник материалов международной научнопрактической конференции (с. 44-48). Екатеринбург: УрФу.

Беда, Г.В. (1981). Основы изобразительной грамоты. Москва: Просвещение.

Краморов, С.М. (2005). Конструктивный рисунок. Омск: Академия.

Лопухова, С.О. (2018). Рисунок у підготовці студентів - майбутніх графічних дизайнерів. Деміург: ідеї, технології, перспективи дизайну, 1, 42-49.

Удріс, І.М. (2017). Формування проектно-образного мислення як провідна складова дизайнерської освіти. В Актуальні проблеми формування естетичної культури майбутніх дизайнерів, Матеріали всеукраїнської науково-практичної конференції (с. 26-28). Кривий Ріг.

Gill, R.W. (1991). Basic rendering. Effective Drawing for Designers, Artists and Illustrators. London: Thames \& Hudson Ltd.

\section{References}

Alieva, O.O., \& Subbotina, T.V. (2018). Osobennosti akademicheskogo risunka v obuchenii dizainerov. In Kulturologicheskie chteniia - 2018. Mezhkulturnyi pliuralizm v polikulturnom i poliiazychnom mire [Culturological Readings - 2018. Intercultural pluralism in a multicultural and multilingual world], Collection of materials from an international scientific and practical conference. Yekaterinburg: UrFU. [in Russian].

Beda, G.V. (1981). Osnovy izobrazitelnoi gramoty [The basics of visual literacy]. Moscow: Prosveshchenie [in Russian].

Kramorov, S.M. (2005). Konstruktivnyi risunok [Constructive drawing]. Omsk: Akademiia [in Russian]. 
Lopukhova, S.O. (2018). Rysunok u pidhotovtsi studentiv - maibutnikh hrafichnykh dyzaineriv [Drawing in preparing students - future graphic designers]. Demiurh: idei, tekhnolohii, perspektyvy dyzainu, 1, 42-49 [in Ukrainian].

Gill, R.W. (1991). Basic rendering. Effective Drawing for Designers, Artists and Illustrators. London: Thames \& Hudson Ltd [in English].

Udris, I.M. (2017). Formuvannia proektno-obraznoho myslennia yak providna skladova dyzainerskoi osvity [Formation of design thinking as a leading component of design education. In Topical problems of formation of aesthetic culture of future designers]. In Aktualni problemy formuvannia estetychnoi kultury maibutnikh dyzaineriv [Actual problems of formation of aesthetic culture of future designers], Materials of the All-Ukrainian scientific-practical conference (pp. 26-28). Kryvyi Rih [in Ukrainian]. 